\title{
ACTIVITY OF THE STATE DEFENSE COMMITTEE ON THE USE OF TROPHIES DURING THE GREAT PATRIOTIC WAR ${ }^{1}$
}

\author{
Anastasiya V. Zotova \\ Saint Petersburg State University, Saint Petersburg, Russian Federation
}

Sergey N. Poltorak

Saint Petersburg Institute of International Trade, Economics and Law, Saint Petersburg, Russian Federation

\begin{abstract}
The article briefly analyzes the historiography of use of the war spoils by the Soviet Union history during the Great Patriotic War. It is noted that, despite the great interest of historians, publicists and journalists, many aspects of the problem are still almost unknown. Among the unstudied side of the history of trophies - the activities of the State Defense Committee on organizing the collection of war trophies, sorting and further transmission to the troops or structures serving the needs of the front. Scientific novelty of article consists in the introduction of the information of documents stored in the Russian state archive of sociopolitical history into scientific circulation. For the first time the authors analyze the content of the decisions and orders of the State Defense Committee on the organization of work of various Soviet and military authorities on the use of trophies in the interests of the national economy. The article traces the dynamics of the use of trophies depending on the situation at the front. It is noted that for the first time the State Defense Committee decided to take control under the use of trophies in January 1942. Since that time, the State Defense Committee supervised the collection and distribution of trophies until the end of the Great Patriotic war, and also after its completion. In this article the activities of the State Defense Committee is considered in the period from January 1942 through May 1945. Collection of trophies was carried out not only in the USSR but also on the territories of Germany, Austria, Finland, Poland, Hungary and Romania. The authors conclude that trophies played a significant role in the development of the Soviet economy during the Great Patriotic war.

Key words: Great Patriotic war, World War II, the spoils of war, State Defense Committee, Soviet economy.

Citation. Zotova A.V., Poltorak S.N. Activity of the State Defense Committee on the Use of Trophies During the Great Patriotic War. Vestnik Volgogradskogo gosudarstvennogo universiteta. Serija 4, Istorija. Regionovedenie. Mezhdunarodnye otnoshenija [Science Journal of Volgograd State University. History. Area Studies. International Relations], 2017, vol. 22, no. 3, pp. 126-135. (in Russian). DOI: https://doi.org/ 10.15688/jvolsu4.2017.3.11.
\end{abstract}

УДК 94(47).084.8

Дата поступления статьи: 18.12.2016

ББК 63.3

Дата принятия статьи: 15.04.2017

\section{ДЕЯТЕЛЬНОСТЬ ГОСУДАРСТВЕННОГО КОМИТЕТА ОБОРОНЫ ПО ИСПОЛЬЗОВАНИЮ ТРОФЕЕВ В ПЕРИОД ВЕЛИКОЙ ОТЕЧЕСТВЕННОЙ ВОЙНЫ ${ }^{1}$}

\author{
Анастасия Валерьевна Зотова \\ Санкт-Петербургский государственный университет, г. Санкт-Петербург, Российская Федерация \\ Сергей Николаевич Полторак \\ Санкт-Петербургский институт внешнеэкономических связей, экономики и права, \\ г. Санкт-Петербург, Российская Федерация
}


Аннотация. В статье кратко анализируется историография, посвященная истории использования военных трофеев Советским Союзом в период Великой Отечественной войны. Отмечается, что, несмотря на большой интерес к этому вопросу историков, публицистов и журналистов, многие его аспекты до сих пор почти не изучены. Среди неизученных сторон истории трофеев - деятельность Государственного Комитета Обороны по организации сбора военных трофеев, их сортировки и дальнейшей передачи в войска или структуры, работавшие на нужды фронта. Научная новизна статьи состоит во введении в научный оборот сведений, почерпнутых из документов, хранящихся в Российском государственном архиве социально-политической истории. Впервые проведен анализ содержания постановлений и распоряжений Государственного Комитета Обороны, касавшихся организации работы различных советских и военных органов по использованию трофеев в интересах отечественной экономики. Прослеживается динамика использования трофеев в зависимости от ситуации, складывавшейся на фронте. Отмечается, что впервые ГКО счел необходимым взять использование трофеев под свой контроль в январе 1942 года. С того времени ГКО осуществлял руководство сбором и распределением трофеев вплоть до конца Великой Отечественной войны, а также и после ее окончания. В настоящей статье деятельность ГКО, связанная с трофеями, рассматривается в период с января 1942 г. по май 1945 года. Приведены сведения о том, что сбор трофеев осуществлялся не только на территории СССР, но и на территориях Германии, Австрии, Финляндии, Польши, Венгрии и Румынии. Авторы делают вывод о том, что трофеи сыграли заметную роль в развитии советской экономики в период Великой Отечественной войны.

Ключевые слова: Великая Отечественная война, Вторая мировая война, военные трофеи, ГКО, советская экономика.

Цитирование. Зотова А. В., Полторак С. Н. Деятельность Государственного Комитета Обороны по использованию трофеев в период Великой Отечественной войны // Вестник Волгоградского государственного университета. Серия 4, История. Регионоведение. Международные отношения. - 2017. - Т. 22, № 3. C. 126-135. - DOI: https://doi.org/10.15688/jvolsu4.2017.3.11.

О трофеях, полученных Красной армией в период Великой Отечественной войны, написано много. Ряд авторов, таких как А.З. Ваксер [1] и Е.С. Сенявская [34], Р.Ф. Гарипов [2], Ю.А. Горьков [3] подробно и основательно писали о трофеях, полученных Советским Союзом в ходе войны и после ее завершения. Особенностью исследования Ю.А. Горькова в отличие от работ других авторов является то, что в нем сочетается анализ историографии проблемы с публикацией новых документов, играющих важную роль в осмыслении деятельности Государственного Комитета Обороны, в том числе и его усилий, нацеленных на эффективное использование трофеев. Тема трофеев затрагивалась в ряде публикаций, которые, скорее, следует отнести к публицистике, а не к научным трудам [5; 40], а также отражена на ряде сайтов [37-39].

Отдельного внимания заслуживают публикации, связанные с историей обороны Сталинграда, поскольку именно в результате героической обороны этого города на местах боев оказалось невиданное прежде в Великой Отечественной войне количество трофеев, которые сыграли важную роль в процессе повышения обороноспособности Советского
Союза. В частности, для исследования проблемы очень важны основательные работы М.M. Загорулько [4; 35; 36]. Важно то, что М.М. Загорулько стал основоположником научной школы, представители которой успешно развивают различные направления деятельности, у истоков которой стоит их учитель [33]. Однако деятельность Государственного Комитета Обороны по использованию военных трофеев специально не изучалась. Она лишь фрагментарно упоминалась в ряде публикаций [6].

Благодаря тому, что многие архивные документы в последние годы стали более доступными, появилась возможность дать оценку деятельности ГКО, нацеленной на использование военных и гражданских трофеев.

Судя по рассекреченным документам, первые трофеи начали рассматриваться Государственным Комитетом Обороны как явление государственного значения с января 1942 года. 16 января того года было принято постановление ГКО, касавшееся вопроса сдачи советским органам гражданами трофейного имущества [7, л. 138-139]. В тот же день было принято и постановление «О ремонте и восстановлении трофейных автомашин, тягачей и мотоциклов» 
[8, л. 142-143]. Спустя две недели, 31 января 1942 г., ГКО принял постановление, касавшееся передачи 100 трофейных автомашин народному комиссариату цветных металлов [9, л. 149].

Вполне понятно, что трофеи как явление войны для нашего государства стали реальностью лишь тогда, когда Красная армия начала одерживать первые крупные победы, сопровождавшиеся быстрым отступлением противника, оставлявшего большое количество поврежденной и неисправной боевой техники. Немало было исправной боевой техники и оружия, которые вермахт оставлял в результате поспешности отступления.

То были поистине боевые трофеи, полученные нашей армией в результате кровопролитных боев. Государственный Комитет Обороны в 1941 - начале 1943 гг. не рассматривал трофеи как постоянный источник пополнения советской оборонной промышленности. До апреля 1943 г. не было необходимости в создании специальных органов, которые руководили бы процессом сбора трофеев, их сортировкой и дальнейшей передачей в войска или структуры, работавшие на нужды фронта.

На протяжении всего 1942 г. и до весны 1943 г. работа ГКО с трофейным имуществом велась в трех направлениях. Оно использовалось в качестве лома черных или цветных металлов, его ремонтировали и адаптировали к нуждам Красной армии. ГКО также занимался распределением отремонтированной или не нуждавшейся в ремонте боевой техники и оружия по воинским соединениям, гражданским и военным учреждениям.

Как минимум одиннадцать рассекреченных на сегодняшний день постановлений ГКО касаются вопросов использования трофейного имущества в указанных трех направлениях. Первые постановления ГКО были весьма просты по своей сути и нацеливались на упорядочение процесса сбора военных трофеев на поле боя. В основном первые военные трофеи использовались в качестве сырья для советских металлургических предприятий. Качественно новый подход использования трофеев появился у членов ГКО лишь в начале 1943 года. 18 января 1943 г. было принято постановление ГКО «Об организации производства самоходных артиллерийских установок
СУ-76 на базе трофейных танков "Артштурм" и Т-3 с 76 мм пушкой Ф-34» [10, л. 11-14].

На следующий день после пленения генерал-фельдмаршала Ф. Паулюса, то есть за сутки до официального завершения битвы под Сталинградом, 1 февраля 1943 г., вышло постановление ГКО «О сборе трофейного имущества на фронтах и обеспечении его хранения» [11, л. 76-78]. Вероятно, трофейным командам хватило трехнедельного срока работы для того, чтобы у членов Государственного Комитета Обороны сложилось четкое представление о масштабах полученных трофеев и их качестве. В результате 24 февраля 1943 г. ГКО издал постановление «О ремонте трофейных танков в районах Сталинграда, Воронежа и Дона» [12, л. 161-162]. Оно было подкреплено распоряжением ГКО от 19 марта того же года [23, л. 33].

Как известно, снабжение германских войск под Сталинградом во многом обеспечивалось за счет грузовых перевозок, осуществлявшихся железнодорожными составами, передвигавшимися по западноевропейской колее. То была крупная проблема для вермахта, которую, в конце концов, германские железнодорожные войска сумели решить. Они сочли целесообразным устанавливать своими силами временную западноевропейскую колею, которая подводилась к центрам снабжения вермахта. После победы Красной армии в Сталинградской битве огромное количество германских вагонов оказалось захваченным советскими войсками. Государственный Комитет Обороны, понимая, что трофейные вагоны могут быть использованы на протяжении длительного периода времени и на разных направлениях советских железных дорог, 12 марта 1943 г. принял постановление «О переделке трофейных вагонов с западноевропейской колеи на широкую колею советских военных дорог» [13, л. 134]. Нетрудно заметить разницу в подходах воевавших сторон к решению одной и той же проблемы: вермахт предпочитал вложить силы и средства в строительство железнодорожной колеи, советская сторона посчитала целесообразным модифицировать железнодорожные вагоны. Представляется, что обе стороны были по-своему правы. Вермахту в условиях войны на чужой территории менее затратно было вкладывать 
средства в строительство новой колеи, которая являлась временной и в строительство которой не вкладывалось много денег. Советская же сторона могла действовать более основательно, ориентируясь не только на долгую перспективу, но и на осознание того, что в ее распоряжении есть немало предприятий, способных заниматься приспособлением зарубежных вагонов к отечественным железнодорожным стандартам.

Итоги Сталинградской битвы давно подведены, но не все стороны победы под Сталинградом оценены по достоинству. В частности, до сих пор никто из отечественных и зарубежных историков не обратил внимания на то обстоятельство, что победа под Сталинградом позволила советскому военно-политическому руководству разглядеть новые тенденции в боевых событиях. В частности, Сталинградская битва стала моментом качественно нового осмысления событий. Успех Красной армии под Сталинградом дал возможность впервые рассмотреть динамику боевых действий июня 1941 - февраля 1943 гг. как единый военно-политический процесс, имевший несомненную положительную динамику для Советского Союза. То была уже не просто победа в одной отдельно взятой битве, а крупная часть войны, подтверждавшая правильность выбранной советской стратегии. Тот опыт следовало закрепить и пропагандировать по горячим следам во всем его величии. Во многом исходя из таких соображений, ГКО издал 13 апреля 1943 г. постановление «О создании музея трофейного вооружения и техники» $[15$, л. 73$]$. Менее чем через месяц оно было дополнено новым постановлением «О музее-выставке трофейного вооружения и техники» [16, л. 163-173], поскольку идея сделать такой музей передвижной выставкой, которую можно было временно разворачивать в различных городах Советского Союза, была вполне плодотворной.

Осознание того, что после победы под Сталинградом боевые действия Красной армии стали началом широкомасштабного наступления наших войск на всех фронтах, привело ГКО к пониманию необходимости качественно новых подходов к осуществлению «трофейной деятельности». Вероятно, в руководстве страны уже не было сомнений в том, что наступила пора подготовки войск к ведению боевых действий на территориях Германии и ее союзников. Это предполагало захват уже не только боевой техники и оружия, но и предприятий, на которых они изготавливались. Не было секретом и то, что побеждавшая сторона считала вполне логичным демонтаж и отправку на территорию СССР оборудования предприятий, не занятых непосредственно в оказании помощи вермахту. Эта работа была еще впереди, но, предвосхищая ее, ГКО принял 5 апреля 1943 г. постановление «О Трофейном комитете при Государственном Комитете Обороны» [14, л. 161].

Весной 1943 г. начался качественно новый период использования трофейной техники. Под нее в широких масштабах уже приспосабливалось советское военное производство, что позволяло, с одной стороны, экономить немало собственных средств, а с другой - весьма эффективно использовать германские и другие зарубежные технологии производства боевой техники, оружия и боеприпасов. С апреля 1943 г. ГКО начал предпринимать более энергичные меры для решения вопросов адаптации трофейной боевой техники, оружия и боеприпасов в условиях применения их советскими войсками. Активным и разнообразным стало использование трофейных боеприпасов. В частности, 23 апреля 1943 г. ГКО принял распоряжение о производстве бугелей к трофейным авиабомбам [24, л. 181-185]. Они представляли собой относительно простое устройство - металлическое кольцо, с помощью которого авиабомбы непривычных габаритов и конфигураций могли устанавливаться на советских самолетах-бомбардировщиках. 27 мая 1943 г. ГКО отдал распоряжение «Об организации производства калибровочных и снаряжательных приспособлений для переделки трофейных боеприпасов» [25, л. 63-64]. К использованию трофейных боеприпасов советские специалисты подходили творчески. Вероятно, не без их рекомендаций было принято постановление ГКО «Об организации производства авиабомб из трофейных артиллерийских снарядов» [17, л. 53-55].

Значительная часть трофейной боевой техники, а также подвижного состава узкой колеи передавалась в тыл на предприятия, работавшие в интересах оборонной промыш- 
ленности. Трофейные узкоколейные паровозы по распоряжению ГКО с августа 1943 г. были заняты на перевозке торфа [26, л. 2], германское железнодорожное оборудование с конца сентября 1943 г. использовалось при восстановлении шахт комбината «Ростовуголь» [27, л. 48]. 3 октября ГКО подписал распоряжение «О разрешении Трофейному комитету при ГКО передать подвижной состав и рельсы для шахт Донбасса» [28, л. 140]. Нашлось применение трофейным паровозам и в Иране, куда в середине ноября того же года было передано 10 паровозов для нужд Советского транспортного управления в этой стране [29, л. 97-99]. Трофейные танки без вооружения в мае 1944 г. были переданы решением ГКО Днепрострою [31, л. 20], остро нуждавшемуся в тягачах.

В мае 1944 г. в числе трофеев впервые у Советского Союза оказались значительные объемы строительных материалов. Распоряжением ГКО от 7 мая строительным организациям Николаева и Херсона, а также народному комиссариату морского флота и Главвоенпромстрою при СНК СССР было передано 10,3 тыс. т трофейного цемента [30, л. 64].

С осени 1944 г. в Советский Союз из-за рубежа началась отправка трофейного оборудования военных и гражданских предприятий, готовой продукции, сырья, природных ресурсов, сельскохозяйственных животных. Трофеи отправлялись не только с территории Германии, но и из Австрии, Финляндии, Польши, Венгрии, Румынии.

Первая отправка состоялась в соответствии с распоряжением ГКО от 27 ноября 1944 г. «О передаче Главснаблесу при СНК СССР 10 тыс. куб. м трофейного леса из Финляндии» [32, л. 191]. По проведенным подсчетам Государственным Комитетом Обороны с того момента до 9 мая 1945 г. было принято не менее 287 постановлений и распоряжений о передислокации трофеев изза границы на территорию Советского Союза. Трофеи вывозились в СССР и позже, уже после подписания Германией акта о беззаговорочной капитуляции.

В соответствии с распоряжениями СНК только весной 1945 г. были демонтированы 19 турбин и 32 котла высокого давления с элект- ростанций немецкой Силезии [18, л. 106-111], из Румынии был вывезен трубопрокатный стан «Штифель» [19, л. 72-73], было вывезено оборудование с немецкого завода нитроглицериновых порохов фирмы «Альфред Нобель и $\mathrm{K}^{\circ} »$ [20, л. 91-92]. 21 марта 1945 г. было принято постановление ГКО «О вывозе оборудования по производству реактивных снарядов с немецких заводов "Гута Банкова" в г. Домброва Гурна и “Ферум" в г. Катовице» [21, л. 168-169]. 19 апреля 1945 г. ГКО принял постановление «О вывозе немецких самолетов-истребителей и моторов с авиазавода "Мессершмидт" в г. Винер-Нойштадт в Австрии» $[22$, л. 16].

Диапазон предприятий и учреждений, подлежавших демонтажу и отправке в СССР, был очень широк: предприятия химической промышленности, радиопромышленности, тяжелого машиностроения, кожевенной промышленности, проектные и научные институты, различные лаборатории, племенные животные, семенной фонд - все это согласно постановлениям ГКО направлялось в Советский Союз в качестве компенсации за разорение германской армией и ее союзниками нашего государства.

О законности или противозаконности принимавшихся постановлений и распоряжений пусть судят правоведы и политики. Историкам очевидно: Государственный Комитет Обороны держал в центре своего внимания вопросы, связанные с использованием трофеев в отечественной экономике. В зависимости от ситуации на фронте политика, проводившаяся ГКО по поводу использования трофеев, оперативно менялась, достигая максимальной эффективности в складывавшейся обстановке. Роль трофеев в достижении Победы Советского Союза в войне была заметной, так как их использование существенно влияло на работу многих отраслей советской экономики.

\section{ПРИМЕЧАНИЕ}

1 Работа выполнена при поддержке гранта Президента Российской Федерации для государственной поддержки молодых российских ученых кандидатов наук (договор от 16 февраля 2015 г. № 14.W01.15.6540-MK). 


\section{СПИСОК ЛИТЕРАТУРЫ}

1. Ваксер, А. З. Сколько получил СССР от побежденной Германии / А. 3. Ваксер // Аргументы и факты. - 1994. - № 20. - С. 4.

2. Гарипов, Р. Ф. Послевоенные платежи Германии Советскому Союзу / Р. Ф. Гарипов // Экономика и управление : науч.-практ. журн. - 2015. № 6. - С. 109-114.

3. Горьков, Ю. А. Государственный Комитет Обороны постановляет (1941-1945) : Цифры, документы / Ю. А. Горьков. - М. : Олма-Пресс, 2002.$575 \mathrm{c}$.

4. Загорулько, М. М. Сталинградская группа войск / М. М. Загорулько. - Электрон. текстовые дан. - Режим доступа: http://www.marshals-victory. senat.org/Stalingrad/Stalingrad-Grupp.html (дата обращения: 14.01.2017). - Загл. с экрана.

5. Кнышевский, П. Н. Добыча. Тайны германских репараций / П. Н. Кнышевский. - М. : Соратник, 1994. - 144 c.

6. Коваль, К. И. Записки уполномоченного ГКО на территории Германии / К. И. Коваль // Новая и новейшая история. - 1994. - № 3. - С. 124-147.

7. Постановление № 1156 от 16 января 1942 г. «О сдаче трофейного имущества» // Российский государственный архив социально-политической истории (далее - РГАСПИ). - Ф. 644. - ОП. 1. - Д. 19.

8. Постановление № 1158 от 16 января 1942 г. «О ремонте и восстановлении трофейных автомашин, тягачей и мотоциклов» // Российский государственный архив социально-политической истории (далее - РГАСПИ). - Ф. 644. - Оп. 1. - Д. 19.

9. Постановление № 1225 от 31 января 1942 г. «О передаче 100 трофейных автомашин НКЦМ» // РГАСПИ. -Ф. 644. - ОП. 1. - Д. 20.

10. Постановление № 2758 от 18 января 1943 г. «Об организации производства самоходных артиллерийских установок СУ-76 на базе трофейных танков “Артштурм” и Т-3 с 76 мм пушкой Ф-34» // РГАСПИ. - Ф. 644. - ОП. 1. - Д. 83.

11. Постановление № 2812 от 1 февраля 1943 г. «О сборе трофейного имущества на фронтах и обеспечении его хранения» // РГАСПИ. - Ф. 644. Оп. 1. - Д. 85.

12. Постановление № 2941 от 24 февраля 1943 г. «О ремонте трофейных танков в районах Сталинграда, Воронежа и Дона» // РГАСПИ. - Ф. 644. Оп. 1.- Д. 91.

13. Постановление № 3029 от 12 марта 1943 г. «О переделке трофейных вагонов с западноевропейской колеи на широкую колею советских железных дорог» // РГАСПИ. - Ф. 644. - Оп. 1. - Д. 96.

14. Постановление № 3123 от 5 апреля 1943 г. «О Трофейном комитете при Государственном Комитете Обороны» // РГАСПИ. -Ф. 644. -Оп. 1. -Д. 100.
15. Постановление № 3177 от 13 апреля 1943 г. «О создании Музея трофейного вооружения и техники» // РГАСПИ. - Ф. 644. - ОП. 1. - Д. 103.

16. Постановление № 3295 от 7 мая 1943 г. «О Музее-выставке трофейного вооружения и техники» // РГАСПИ. - Ф. 644. - ОП. 1. - Д. 113.

17. Постановление № 4195 от 24 сентября 1943 г. «Об организации производства авиабомб из трофейных артиллерийских снарядов» // РГАСПИ. Ф. 644. - Оп. 1. - Д. 153.

18. Постановление № 7614 от 2 марта 1945 г. «О демонтаже 19 турбин на мощность 507 тыс. киловатт и 32 котлов высокого давления с электростанций немецкой Силезии» // РГАСПИ. - Ф. 644. Оп. 1. -Д. 373.

19. Постановление № 7631 от 3 марта 1945 г. «Об установке трубопрокатного стана “Штифель", вывозимого из Румынии» // РГАСПИ. - Ф. 644. Оп. 1. - Д. 376.

20. Постановление № 7687 от 6 марта 1945 г. «О вывозе оборудования с немецкого завода нитроглицериновых порохов фирмы “Альфред Нобель и К ${ }^{\circ}$ ” г. Бромберг (Быгдощ)» // РГАСПИ. - Ф. 644. Оп. 1. - Д. 377.

21. Постановление № 7876 от 21 марта 1945 г. «О вывозе оборудования по производству реактивных снарядов с немецких заводов "Гута Банкова" в г. Домброва Гурна и “Ферум” в г. Катовице» // РГАСПИ. - Ф. 644. - ОП. 1. - Д. 382.

22. Постановление № 8196 от 19 апреля 1945 г. «О вывозе немецких самолетов-истребителей и моторов с авиазавода "Мессершмидт" в г. Винер-Нойштадт в Австрии» // РГАСПИ. - Ф. 644. - ОП. 1. Д. 402.

23. Распоряжение № 3053 от 19 марта 1943 г. «О мерах по выполнению постановления ГКО № 2941 от 24 февраля 1943 г. “О ремонте трофейных танков в районах Сталинграда, Воронежа и Дона”» // РГАСПИ. - Ф. 644. - ОП. 1. - Д. 98.

24. Распоряжение № 3242 от 23 апреля 1943 г. «О производстве бугелей к трофейным авиабомбам» // РГАСПИ. - Ф. 644. - Оп. 1. - Д. 109.

25. Распоряжение № 3442 от 27 мая 1943 г. «Об организации производства калибровочных и снаряжательных приспособлений для переделки трофейных боеприпасов» // РГАСПИ. - Ф. 644. - Оп. 1. Д. 120.

26. Распоряжение № 3868 от 4 августа 1943 г. «О передаче НКЭС 10 трофейных узкоколейных паровозов для вывозки торфа» // РГАСПИ. - Ф. 644. Оп. 1.-Д. 143.

27. Распоряжение № 4191 от 24 сентября 1943 г. «О передаче Трофейным комитетом при ГКО железнодорожного оборудования для восстановления шахт комбината "Ростовуголь"» // РГАСПИ. Ф. 644.-Оп. 1. - Д. 153. 
28. Распоряжение № 4226 от 3 октября 1943 г. «О разрешении Трофейному комитету при ГКО передать подвижной состав и рельсы для шахт Донбасса» // РГАСПИ. - Ф. 644. - ОП. 1. - Д. 154.

29. Распоряжение № 4586 от 16 ноября 1943 г. «О выделении в распоряжение Советского транспортного управления в Иране 10 трофейных паровозов» // РГАСПИ. - Ф. 644. - ОП. 1. - Д. 175.

30. Распоряжение № 5832 от 7 мая 1944 г. «О выделении 10,3 тыс. т трофейного цемента в Николаеве и Херсоне Наркомстрою, НКСП, НКМФ и Главвоенпромстрою при СНК СССР» // РГАСПИ. Ф. 644. - Оп. 1. - Д. 251.

31. Распоряжение № 5940 от 21 мая 1944 г. «О передаче Днепрострою НКЭС 20 трофейных ходовых танков без вооружения» // РГАСПИ. Ф. 644. - Оп. 1. - Д. 255.

32. Распоряжение № 7014 от 27 ноября 1944 г. «О передаче Главснаблесу при СНК СССР 10 тыс. куб. м трофейного леса из Финляндии» // РГАСПИ. Ф. 644. - Оп. 1. - Д. 335.

33. Редькина, О. Ю. Научная школа профессора М.М. Загорулько / О. Ю. Редькина, В. В. Булатов // Вестник Волгоградского государственного университета. Серия 4, История. Регионоведение. Международные отношения. - 2013. - № 2 (24). - С. 190-198.

34. Сенявская, Е. С. «Это наши законные трофеи...» система организации посылок из действующей Красной армии в 1945 г. по рассекреченным архивным документам / Е. С. Сенявская // Былые годы. - 2013. - № 3. - С. 75-95.

35. Сталинградская группа войск, февраль май 1943 г. : док. и материалы / сост.: М. М. Загорулько и др. ; под ред. М. М. Загорулько. - Волгоград : Издатель, 2004. - 263 с.

36. Сталинградская область в постановлениях Государственного Комитета Обороны (1943-1945): док. и материалы / под ред. М. М. Загорулько. Волгоград : Издатель, 2011. - 783 с.

37. Трофеи без грифа «секретно»: Красноармейцы отсылали из Европы не золотые кольца, а иголки и рубанки. - Электрон. текстовые дан. - Режим доступа: http://www.spb.kp.ru/daily/26364/3247648/ (дата обращения: 15.11.2016). - Загл. с экрана.

38. Трофейная служба в годы Великой Отечественной войны. - Электрон. текстовые дан. - Режим доступа: http:/www.oboznik.ru/?p=11576 (дата обращения: 14.11.2016). - Загл. с экрана.

39. Трофейное вооружение на службе РККА и вермахта. - Электрон. текстовые дан. - Режим доступа: http://beloepyatno.blogspot.ru/2010/05/ blog-post_04.html (дата обращения: 15.11.2016). Загл. с экрана.

40. Широкорад, А. Б. Великая контрибуция. Что СССР получил после войны / А. Б. Широкорад. М. : Вече, 2013. -384 c.

\section{REFERENCES}

1. Vakser A.Z. Skolko poluchil SSSR ot pobezhdennoy Germanii [How Much the USSR Got from the Defeated Germany]. Argumenty i fakty, 1994, no. 20 , p. 4 .

2. Garipov R.F. Poslevoennye platezhi Germanii Sovetskomu Soyuzu [Post-War Payments by Germany to the Soviet Union]. Ekonomika $i$ upravlenie: nauchno-prakticheskiy zhurnal, 2015, no. 6, pp. 109114.

3. Gorkov Yu.A. Gosudarstvennyy Komitet Oborony postanovlyaet (1941-1945): Tsifry, dokumenty [The State Committee of Defense Enacts (1941-1945). Figures, Documents]. Moscow, OlmaPress Publ., 2002. 575 p.

4. Zagorulko M.M. Stalingradskaya gruppa voisk [The Stalingrad Group of Forces]. URL: http:// www.marshals-victory. senat.org/Stalingrad/ Stalingrad-Grupp.html. (accessed 14.01.2017).

5. Knyshevskiy P.N. Dobycha. Tayny germanskikh reparatsiy [Mining. Secrets of German Reparations]. Moscow, Soratnik Publ., 1994. 144 p.

6. Koval K.I. Zapiski upolnomochennogo GKO na territorii Germanii [Notes of the Commissioner of the State Defense Committee in Germany]. Novaya $i$ noveyshaya istoriya [Modern and Contemporary History], 1994, no. 3, pp. 124-147.

7. Postanovlenie № 1156 ot 16 yanvarya $1942 \mathrm{~g}$. «O sdache trofeynogo imushchestva» [Resolution no. 1156 of January 16, 1942 “On the Surrender of Captured Property"]. Rossiyskiy gosudarstvennyy arkhiv sotsialno-politicheskoy istorii [Russian State Archive of Socio-Political History], F. 644, Op. 1, D. 19.

8. Postanovlenie № 1158 ot 16 yanvarya $1942 \mathrm{~g}$. «O remonte i vosstanovlenii trofeynykh avtomashin, tyagachey i mototsiklov» [Resolution no. 1158 of January 16, 1942 "On the Repair and Restoration of Captured Vehicles, Tractors and Motorcycles"]. Rossiyskiy gosudarstvennyy arkhiv sotsialnopoliticheskoy istorii [Russian State Archive of SocioPolitical History], F. 644, Op. 1, D. 19.

9. Postanovlenie № 1225 ot 31 yanvarya $1942 \mathrm{~g}$. «O peredache 100 trofeynykh avtomashin NKTsM» [Resolution no. 1225 of January 31, 1942 "On the Transfer of 100 Captured Vehicles to the People's Commissariat"]. Rossiyskiy gosudarstvennyy arkhiv sotsialno-politicheskoy istorii [Russian State Archive of Socio-Political History], F. 644, Op. 1, D. 20.

10. Postanovlenie № 2758 ot 18 yanvarya $1943 \mathrm{~g}$. «Ob organizatsii proizvodstva samokhodnykh artilleriiskikh ustanovok SU-76 na baze trofeinykh tankov Artshturm i T-3 s 76 mm pushkoi F-34» [Resolution no. 2758 of January 18, 1943 “About the Organization of Production of Self-Propelled Artillery SU-76 on the Basis of the Captured Tanks "Artstorm" 
and T-3 with $76 \mathrm{~mm}$ Gun F-34"]. Rossiyskiy gosudarstvennyy arkhiv sotsialno-politicheskoy istorii [Russian State Archive of Socio-Political History], F. 644, Op. 1, D. 83.

11. Postanovlenie № 2812 ot 1 fevralya 1943 g. «O sbore trofeynogo imushchestva na frontakh i obespechenii ego khraneniya» [Resolution no. 2812 of February 1, 1943 "On the Collection of Captured Property on the Fronts and the Provision of Its Storage"]. Rossiyskiy gosudarstvennyy arkhiv sotsialno-politicheskoy istorii [Russian State Archive of Socio-Political History], F. 644, Op. 1, D. 85.

12. Postanovlenie № 2941 ot 24 fevralya 1943 g. «O remonte trofeynykh tankov v raionakh Stalingrada, Voronezha i Dona» [Resolution no. 2941 of February 24, 1943 "About the Repair of Captured Tanks in the Districts of Stalingrad, Voronezh and the Don"]. Rossiyskiy gosudarstvennyy arkhiv sotsialnopoliticheskoy istorii [Russian State Archive of SocioPolitical History], F. 644, Op. 1, D. 91.

13. Postanovlenie № 3029 ot 12 marta 1943 g. «O peredelke trofeynykh vagonov s zapadnoevropeiskoi kolei na shirokuyu koleyu sovetskikh zheleznykh dorog» [Resolution no. 3029 of March 12, 1943 “About Converting the Captured Wagons from the Western European Gauge to Broad Gauge of Soviet Railways"]. Rossiyskiy gosudarstvennyy arkhiv sotsialnopoliticheskoy istorii [Russian State Archive of SocioPolitical History], F. 644, Op. 1, D. 96.

14. Postanovlenie № 3123 ot 5 aprelya 1943 g. «O Trofeynom komitete pri Gosudarstvennom Komitete Oborony» [Resolution no. 3123 of April 5, 1943 “About the Trophy Committee of the State Committee of Defense"]. Rossiyskiy gosudarstvennyy arkhiv sotsialno-politicheskoy istorii [Russian State Archive of Socio-Political History], F. 644, Op. 1, D. 100.

15. Postanovlenie № 3177 ot 13 aprelya 1943 g. «O sozdanii Muzeya trofeinogo vooruzheniya i tekhniki» [Resolution no. 3177 of April 13, 1943 “On the Creation of the Museum of Captured Weapons and Equipment"]. Rossiyskiy gosudarstvennyy arkhiv sotsialno-politicheskoy istorii [Russian State Archive of Socio-Political History], F. 644, Op. 1, D. 103.

16. Postanovlenie № 3295 ot 7 maya 1943 g. «O Muzee-vystavke trofeynogo vooruzheniya i tekhniki» [Resolution no. 3295 of May 7, 1943 “About the Museum-Exhibition of Captured Weapons and Equipment"]. Rossiyskiy gosudarstvennyy arkhiv sotsialno-politicheskoy istorii [Russian State Archive of Socio-Political History], F. 644, Op. 1, D. 113.

17. Postanovlenie № 4195 ot 24 sentyabrya 1943 g. «Ob organizatsii proizvodstva aviabomb iz trofeynykh artilleriyskikh snaryadov» [Resolution no. 4195 of September 24, 1943 "About the Organization of Production of Bombs from Captured Artillery Shells"]. Rossiyskiy gosudarstvennyy arkhiv sotsialno- politicheskoy istorii [Russian State Archive of SocioPolitical History], F. 644, Op. 1, D. 153.

18. Postanovlenie № 7614 ot 2 marta 1945 g. «O demontazhe 19 turbin na moshchnost 507 tys. kilovatt i 32 kotlov vysokogo davleniya $\mathrm{s}$ elektrostantsiy nemetskoy Silezii» [Resolution no. 7614 of March 2, 1945 'On the Dismantling of 19 Turbines for the Capacity of 507 Thousand Kilowatts and 32 High-Pressure Boilers of Power Plants of German Silesia"]. Rossiyskiy gosudarstvennyy arkhiv sotsialno-politicheskoy istorii [Russian State Archive of Socio-Political History], F. 644, Op. 1, D. 373.

19. Postanovlenie № 7631 ot 3 marta 1945 g. «Ob ustanovke truboprokatnogo stana "Shtifel", vyvozimogo iz Rumynii» [Resolution no. 7631 of March 3, 1945 "About the Installation of a Tube Mill "Stiefel" Exported from Romania"]. Rossiyskiy gosudarstvennyy arkhiv sotsialno-politicheskoy istorii [Russian State Archive of Socio-Political History], F. 644, Op. 1, D. 376.

20. Postanovlenie № 7687 ot 6 marta 1945 g. «O vyvoze oborudovaniya s nemetskogo zavoda nitroglitserinovykh porokhov firmy "Alfred Nobel i Ko” g. Bromberg (Bygdoshch)» [Resolution no. 7687 of March 6, 1945 “About the Removal of Equipment from German Plant of Nitroglycerin Propellants of the Company Alfred Nobel and Co. of the city of Bromberg (Bydgoszcz)"]. Rossiyskiy gosudarstvennyy arkhiv sotsialno-politicheskoy istorii [Russian State Archive of Socio-Political History], F. 644, Op. 1, D. 377.

21. Postanovlenie № 7876 ot 21 marta 1945 g. «O vyvoze oborudovaniya po proizvodstvu reaktivnykh snaryadov s nemetskikh zavodov "Guta Bankova" v g. Dombrova Gurna i "Ferum" v g. Katovitse» [Resolution no. 7876 of March 21, 1945 "On the Export of Equipment for the Production of Missiles from German Factories Guta Bank in the City of Dombrova Gurna and Ferum in Katowice"]. Rossiyskiy gosudarstvennyy arkhiv sotsialnopoliticheskoy istorii [Russian State Archive of SocioPolitical History], F. 644, Op. 1, D. 382.

22. Postanovlenie № 8196 ot 19 aprelya 1945 g. «O vyvoze nemetskikh samoletov-istrebiteley i motorov s aviazavoda "Messershmidt" v g. Viner-Noyshtadt v Avstrii» [Resolution no. 8196 of April 19, 1945 “About the Export of German Fighter Aircraft and Engines from the Aircraft Factory Messerschmitt in Wiener Neustadt,Austria"]. Rossiyskiy gosudarstvennyy arkhiv sotsialno-politicheskoy istorii [Russian State Archive of Socio-Political History], F. 644, Op. 1, D. 402.

23. Rasporyazhenie № 3053 ot 19 marta 1943 g. «O merakh po vypolneniyu postanovleniya GKO № 2941 ot 24 fevralya 1943 g. "O remonte trofeynykh tankov v rayonakh Stalingrada, Voronezha i Dona"»" [Order no. 3053 of March 19, 1943 “On Measures for Implementation of the Resolution of the State Defense Committee no. 2941 of February 24, 1943 'About the 
Repair of Captured Tanks in the Districts of Stalingrad, Voronezh and the Don"']. Rossiyskiy gosudarstvennyy arkhiv sotsialno-politicheskoy istorii [Russian State Archive of Socio-Political History], F. 644, Op. 1, D. 98.

24. Rasporyazhenie № 3242 ot 23 aprelya 1943 g. «O proizvodstve bugeley k trofeynym aviabombam» [Order no. 3242 of April 23, 1943 "On the Production of Drags for Trophy Bombs"]. Rossiyskiy gosudarstvennyy arkhiv sotsialno-politicheskoy istorii [Russian State Archive of Socio-Political History], F. 644, Op. 1, D. 109.

25. Rasporyazhenie № 3442 ot 27 maya $1943 \mathrm{~g}$. «Ob organizatsii proizvodstva kalibrovochnykh i snaryazhatelnykh prisposobleniy dlya peredelki trofeynykh boepripasov» [Order no. 3442 of May 27, 1943 "About the Organization of Production of Calibration Equipment and Fixtures for Reworking Captured Ammunition"]. Rossiyskiy gosudarstvennyy arkhiv sotsialno-politicheskoy istorii [Russian State Archive of Socio-Political History], F. 644, Op. 1, D. 120.

26. Rasporyazhenie № 3868 ot 4 avgusta 1943 g. «O peredache NKES 10 trofeynykh uzkokoleynykh parovozov dlya vyvozki torfa» [Order no. 3868 of August 4, 1943 "On the Transfer of Captured 10 Narrow Gauge Locomotives for Hauling Peat to the People's Commissariat of Power Plants"]. Rossiyskiy gosudarstvennyy arkhiv sotsialno-politicheskoy istorii [Russian State Archive of Socio-Political History], F. 644, Op. 1, D. 143.

27. Rasporyazhenie № 4191 ot 24 sentyabrya 1943 g. «O peredache Trofeynym komitetom pri GKO zheleznodorozhnogo oborudovaniya dlya vosstanovleniya shakht kombinata "Rostovugol"» [Resolution no. 4191 of September 24, 1943 “On the Transfer of Railway Equipment for Mine Rehabilitation of the Plant "Rostovugol" by the Trophy Committee under the State Committee of Defense"]. Rossiyskiy gosudarstvennyy arkhiv sotsialno-politicheskoy istorii [Russian State Archive of Socio-Political History], F. 644, Op. 1, D. 153.

28. Rasporyazhenie № 4226 ot 3 oktyabrya 1943 g. «O razreshenii Trofeynomu komitetu pri GKO peredat podvizhnoy sostav i relsy dlya shakht Donbassa» [Order no. 4226 of October 3, 1943 "On the Resolution of the Trophy Committee of the State Committee of Defense to Transfer Rolling Stock and Rails for Mines of Donbass"]. Rossiyskiy gosudarstvennyy arkhiv sotsialno-politicheskoy istorii [Russian State Archive of Socio-Political History], F. 644, Op. 1, D. 154.

29. Rasporyazhenie № 4586 ot 16 noyabrya 1943 g. «O vydelenii v rasporyazhenie Sovetskogo transportnogo upravleniya v Irane 10 trofeynykh parovozov» [Resolution no. 4586 of November 16, 1943 "On the Allocation of 10 Trophy Locomotives at the Disposal of the Soviet Transport Management in Iran"]. Rossiyskiy gosudarstvennyy arkhiv sotsialno- politicheskoy istorii [Russian State Archive of SocioPolitical History]. F. 644, Op. 1, D. 175.

30. Rasporyazhenie № 5832 ot 7 maya $1944 \mathrm{~g}$. «O vydelenii 10,3 tys. $\mathrm{t}$ trofeynogo tsementa $\mathrm{v}$ Nikolaeve i Khersone Narkomstroyu, NKSP, NKMF i Glavvoenpromstroyu pri SNK SSSR» [Order no. 5832 of May 7, 1944 "On the Allocation of 10,3 Thousand Tons of Trophy Cement in Nikolaev and Kherson to Narkomstroy, the People's Commissariat of Shipbuilding Industry, the People's Commissariat of the Navy and the Main Directorate of Military Industrial Engineering under the Council of People's Commissars"]. Rossiyskiy gosudarstvennyy arkhiv sotsialno-politicheskoy istorii [Russian State Archive of Socio-Political History], F. 644, Op. 1, D. 251.

31. Rasporyazhenie № 5940 ot 21 maya $1944 \mathrm{~g}$. «O peredache Dneprostroyu NKES 20 trofeynykh kho dovykh tankov bez vooruzheniya» [Order no. 5940 of May 21, 1944 "On the Transfer of Power Plants of 20 Captured Tanks Running without Weapons to Dneprostroy under the People's Commissariat"]. Rossiyskiy gosudarstvennyy arkhiv sotsialnopoliticheskoy istorii [Russian State Archive of SocioPolitical History], F. 644, Op. 1, D. 255.

32. Rasporyazhenie № 7014 ot 27 noyabrya $1944 \mathrm{~g}$. «O peredache Glavsnablesu pri SNK SSSR 10 tys. kub. $\mathrm{m}$ trofeynogo lesa iz Finlyandii» [Order no. 7014 of November 27, 1944 "On the Transfer of 10 Thousand Cubic Meters of Forest Captured from Finland to the Main Forest Logistics Management under Council of People's Commissars"]. Rossiyskiy gosudarstvennyy arkhiv sotsialno-politicheskoy istorii [Russian State Archive of Socio-Political History], F. 644, Op. 1, D. 335.

33. Redkina O.Yu., Bulatov V.V. Nauchnaya shkola professora M.M. Zagorulko [Scientific School of Professor M. M. Zagorulko]. Vestnik Volgogradskogo gosudarstvennogo universiteta. Seriya 4, Istoriya. Regionovedenie. Mezhdunarodnye otnosheniya [Science Journal of Volgograd state University. History. Area Studies. International Relations], 2013, no. 2 (24), pp. 190-198.

34. Senyavskaya E.S. «Eto nashi zakonnye trofei...» sistema organizatsii posylok iz deystvuyushchey krasnoy armii v 1945 g. po rassekrechennym arkhivnym dokumentam ["These are our Legal Trophies..." the System of Organization of the Packages of the Red Army in 1945, according to Declassified Archival Documents]. Bylye gody, 2013, no. 3, pp. 75-95.

35. Zagorulko M.M., ed. Stalingradskaya gruppa voysk, fevral - mai 1943 g.: dokumenty $i$ materialy [The Stalingrad Group of Forces, February May 1943: Documents and Materials]. Volgograd, Izdatel Publ., 2004. 263 p.

36. Zagorulko M.M., ed. Stalingradskaya oblast $v$ postanovleniyakh Gosudarstvennogo Komiteta Oborony (1943-1945): dokumenty i materialy [The 
Stalingrad Region in the Decrees of the State Defense Committee (1943-1945): Documents and Materials]. Volgograd, Izdatel Publ., 2011. 783 p.

37. Trofei bez grifa «sekretno»: Krasnoarmeytsy otsylali iz Evropy ne zolotye koltsa, a igolki i rubanki [Trophies without Mark "Secret": the Red Army Soldiers Sent out from Europe not Gold Rings, but Needles and Planes]. URL: http://www.spb.kp.ru/daily/ 26364/3247648/ (accessed November 15, 2016).

38. Trofeynaya sluzhba $v$ gody Velikoy Otechestvennoy voyny [Trophy Service during the
Great Patriotic War]. URL: http://www.oboznik.ru/ $? \mathrm{p}=11576$ (accessed November 14, 2016).

39. Trofeynoe vooruzhenie na sluzhbe RKKA $i$ vermakhta [Captured Weapons in the Service of the Red Army and the Wehrmacht]. URL: http:// beloepyatno.blogspot.ru/2010/05/blog-post_04.html (accessed November 15, 2016)

40. Shirokorad A.B. Velikaya kontributsiya. Chto SSSR poluchil posle voyny [Great Contribution. What the USSR Received after the War]. Moscow, Veche Publ., 2013. 384 p.

\section{Information About the Authors}

Anastasiya V. Zotova, Doctor of Sciences (History), Associate Professor, Department of International Relations in the Post-Soviet Area, Saint Petersburg State University, Universitetskaya Emb., 7-9, 199034 Saint Petersburg, Russian Federation, anastasiyazotova@mail.ru, http://orcid.org/0000-0001$7791-6867$

Sergey N. Poltorak, Doctor of Sciences (History), Professor, Editor-in-Chief of the Scholary Journal Klio, Head of the Department of International Relations and Foreign Area Studies, Saint Petersburg Institute of International Trade, Economics and Law, Prosp. Liteyny, 42, 191014 Saint Petersburg, Russian Federation, anastasiyazotova@mail.ru, http://orcid.org/0000-0001-9247-5553

\section{Информация об авторах}

Анастасия Валерьевна Зотова, доктор исторических наук, доцент кафедры международных отношений на постсоветском пространстве, Санкт-Петербургский государственный университет, Университетская наб., 7-9, 199034 г. Санкт-Петербург, Российская Федерация, anastasiyazotova@mail.ru,http://orcid.org/0000-0001-7791-6867

Сергей Николаевич Полторак, доктор исторических наук, профессор, главный редактор журнала для ученых «Клио», заведующий кафедрой международных отношений и зарубежного регионоведения, Санкт-Петербургский институт внешнеэкономических связей, экономики и права, просп. Литейный, 42, 191014 г. Санкт-Петербург, Российская Федерация, anastasiyazotova@mail.ru, http://orcid.org/0000-0001-9247-5553 